\title{
Implementation of Auteur Theory in The Butler (2013): Race-Relationship between Whites and Blacks
}

\author{
Triastama Wiraatmaja
}

English Language Education Department, University of Muhammadiyah

Malang

triastama@umm.ac.id

\begin{abstract}
The objectives of this study are to show the depiction of racism, which are followed by prejudice and discrimination towards black Americans based on context-relationship with The Butler (2013) during 1920s until 1960s. This article used a qualitative method with auteur theory, mise-en-scene and thick description. Based on The Butler (2013), this study show that racism, which were followed by prejudice and discrimination towards blacks, emerged caused by slavestereotyping which stressed blacks as inferior and whites that uphold white-supremacy concept, as superior. Apparently that through The Butler, Lee Daniels wants to highlight that actually public policies or government laws which regulate citizens' civil rights and slavery are not adequate to restrain or eradicate racism towards blacks American.
\end{abstract}

Keyword(s) : auteur theory; discrimination; Lee Daniels; mise-en-scene; prejudice; racism; stereotype; thick description; white supremacy. 


\section{INTRODUCTION}

The candicacy and election of Barack Husein Obama Jr. for the president of United States ofAmerica in 2008 inspired Wil Haygood, African-American journalist from The Washington Post, to compose an article which title is $A$ Butler Well Served by This Election (2008). The article written by Haygood retold the biography of a distinguished individual named $\mathrm{Eu}-$ gene Allen ${ }^{1}$; he was a living-witness of an African-American who served at White House as a butler during 1952-1986, an era which known as turmoil years ofCivil Rights Movements during 1950s until he finally resigned during Ronald Reagan's administration in 1986.

Lee Daniels, the producer of The Butler, has an intention to prevail that a butler which always been considered as an outcast actually have important roles to resist racism towards black American. The Butler also expected to link up between African-American with its audiences, which mostly American's citizens and movie lovers. This movie, thus regards has successfully resembled Lee Daniels's perspective that will be explained further by auteur theory. The significance of Auteur Theory ${ }^{2}$ is actually underlying how the producer as the story teller or to orchestrate the whole movies by attempting to reveal producer's perspectives or thoughts towards their audiences. Hence, Lee Daniels as the producer of The Butler want to emphasise that racism still exist in America between 1920s until Barack Husein Obama was elected as the first black American President in United States ofAmerica in 2008.

\footnotetext{
${ }^{1}$ Biography.com Editors. Eugene Allen Biography. 2013. http://www.biography.com/people/eugene-allen-21095473. 6 Januari 2016

${ }^{2}$ Auteur Theory. Doree Shafrir. Accessed on September 19th 2015 at 10.00 , downloaded from http://sharepoint. mvla.net/teachers/GalenR/Film\%20Analysis/Documents/ Class\%20Readings/AUTEUR\%20THEORY.pdf
}

Within this movie which released in 2013, Lee Daniels tried to display about racism which implemented by prejudice and discrimination towards blacks American by White American. Moreover, this movie also depict the struggle of the main character, Cecil Gaines, who tried to cut ties with slavery and racism in the South, thus The Butler also display Cecil struggle as black butler in White House during Civil Rights Movements in 1960s. As a producer, Lee Daniels was inspired to produce this movie due to the election Obama as the first black American President. Furthermore, the researcher's point of view via Auteur Theory, Lee Daniels wants to deliver a message and depict his thoughts, from the perspectives of black butler named Cecil Gaines, regarding African-American struggle against racism from white people that emerge due to prejudice and discrimination.

Based on this movie, the researcher deemed that Lee Daniels was trying to emphasise his opinion regarding racism which symbolise by prejudice and discrimination towards black American during civil rights era from the perspective of a black American butler in White House.

Eventhough Emancipation Proclamation, which are the $13^{\text {rd }}$ and $15^{\text {th }}$ had been implemented into United States government, however, racism towards African-Americans during 1920s-1960s still do exist, as depicted by Lee Daniels within the movie The Butler (2013). Furthermore, the research question inquired in this research is; based on this movie, how is the resemblance of the relation between racism during civil rights movements and and its' relation to the resemblance of racismin the social condition of modern society in United States of America today? 


\section{THEORETICAL STUDY}

\section{Racism and Racist Ideology}

In race-relation concept and its' connection to racism, the majority ethnic group or the superior group surely will try to assert or maintain their dominance. By which, the superior group utilises the concept of racism as a tool to assert or to maintain their dominance over the inferior group. This argument justifies by Ferris and Stein (2010:249) as follow, an ideology or set of beliefs about the superiority of one racial or ethnic group over another provides this support; it is used to justify social arrangements between the dominant and minority groups.

Based on that premiss, racism could be defined as an ideology in which defining that a particular ethnic group or race has a higher position or superiority feeling over others ethnic group or races, hence that superiority feeling strengthen the concept of the gap between social class; superior group as the dominant or majority and the inferior group as the minority. Racism itself are employed by white's people at their disposal who holds dear their racist ideology, by that causing the differences in social status between white's as the superior and black's as the inferior based on the biological make-up.

The researcher argues that ideology might be utilised as a tool of propaganda by particular group of people to achieve their goals, in which mostly related to their political agenda. This is how Clifford Geertz (1974:193) explain about ideology

It is one of the minorironies of modern intellectual history that the term "ideology" has itself become thoroughly ideologized. A concept that once meant but a collection of political proposal, perhaps some what intellectualistics and impractical but at any rate idealistic"social-romances" as someone, perhaps Napoleon, called them- has now be- come, to quote Webster's, "the integrated assertions, theories , and aims constituting a politico-social program, often with an implication of factitious propagandazing.

Knowing that, the term ideology keeps changing overtime; hence, the term ideology has evolved to be highly correlated to social concepts and politics which have a tendency as a tool of propaganda.

Ideology is a portion of culture might be recognised through signs and symbols. As Geertz (1973:89) briefly explain, culture is a system of inherited conceptions expressed in symbolic forms by means of which men communicate, perpetuate, and develop their knowledge about and attitudes towards life. Basing on that premiss, the researcher argues that symbolism is a concept which highly associated with another concept to show the signs, representations or particular meaning which derived form values in life. To reveal those symbols, I also basing on Geertz (1973:12) argument, Culture is public, because meaning is. Based on that, the researcher argues that symbols might be interpreted as utterances or statements and actions within society.

The history of slavery in America which closely related to the African-American and its' descendant becoming the reason of the white supremacist or the white's as majority group hold dear their racist ideology which allows them to employ racism towards people of colour, especially, African-American. Moreover, white supremacist ideology in the form of racism also emphasising the superiority feeling over African American, as subordinate, based on the differences in race, skin complexion, and physical trait. The white's people who extremely adhere to the teaching of the racist ideology could be explain by Ferrante (2007:252) as follow,

People who embrace racist ideology believe that something in the biological makeup of 
an ethnic or racial group explains and justifies its subordinate or superior status. Racist ideologies are structured around three notions:

1. People can be classified according to physical characteristics.

2. A close correspondence exists between physical traits and characteristics such as language, dress, personality, intelligence, and athletic ability.

3. Physical attributes such as skin color and hair texture are so significant that they explain and determine behavior and inequalities.

The researcher argues that the images of slaves were being embedded to the AfricanAmerican because of the stereotyped that being manifested by the white's people to AfricanAmerican. According to Hess, Markson, and Stein (1993:256), stereotyped itself might be defined as, an image in which a single set of characterictics, favorable orunfavorable, is attributed to entire group. In addition, the researcher argues that the specific stereotyped towards AfricanAmerican could be regards as, barbaric, lazy, uneducated, and inferior. Those kinds of stereotyped were being developed since the arrival of the first British Settlers in America in $17^{\text {th }}$ century, also that kind of stereotyped emerged because at that era the British communites view the black's people from Africa as an inferior groups and come from low social-class. This concept also explained by Tindall (2013:118) as follows;

The English in the seventeenth century associated the color black with darkness and evil; they stamped the different appearance, behavior, and customs of Africans as "savagery." Most of the self-serving qualities that colonial Virginians imputed to blacks to justify slavery were the same qualities that the English assigned to their own poor to explain their lowly status: their alleged bent for laziness, treachery, and stupidity, among other shortcomings.

As a result, the stereotyped towards the inferior group, especially African-American, grew larger and causing superiority feeling among the white's people in United States of America, specifically for those who are the descendant of the WhiteAnglo-Saxon-Protestant.Arguably, what explains a lot about the relation between superior and inferior groups is that the relation between the slave's owner who were mainly from white's people, strengthen the concept that the black's were belong as slaves, who at that time were seen as commodities.

The superior feeling among whites grows overtime, and lead to racism towards AfricanAmerican which being utilised as prejudiced and discrimination over them. According to Hess, Markon, and Stein (1993:256), prejudice might be defined as prejudging without knowledge.

Moreover, based on Horton and Chester (1984:234), discrimination defined as discrimination involves actual behaviour; favoring one person or penalizing another because of that individual's ethnic status. It usually surfaces when members ofa dominant group deny equal treatment to subordinate group. Basing on that premiss, discrimination could be well inferred as an actual behaviour which favour someone based on their ethnic group, and that particular behaviour emerged because the dominant group refused to treat the inferior group equally.

In other words, in its' relation to The Butler, prejudice is a negative attitude or signs of disrespect towards other groups or people who possess difference characteristics without knowing adequate knowledge or understanding. The discriminatory practises from white's people in The Butler also emphasis the innumerable injustice against AfricanAmerican, that was constituted because of the differences in social class, race, and skin complexion.

The researcher argues that both prejudice and discrimination are part of the tools utilised by white's society to assert their dominance over 
the inferior group, especially blacks, significantly if the inferior group are declaring resistance towards dominant group. This premiss was supported by Kornblum, Julian and Smith (1995:256) as follow;

\begin{abstract}
prejudice and discriminations are weapons used by a dominant group to maintain its dominance. It would be a mistake, however, to see them as always, or even usually, consciously used weapons. Unless the subordinate group mounts a serious challenge to the dominant group, prejudice and discrimination are likely to seem part of the natural order of things.
\end{abstract}

The researcher not only utilised the concepts of racism, ideology, stereotyped, prejudice, and discrimination to analyse racism between racerelationship among white's and black's in The Butler, but also utilising the concept of values. Values according to Spradley and Rynkiewich in Kurniadi (2012:13) defined as, conceptions of what are desirable. As assumptions what ought to be, they shape every aspect of people's lives. Values are ideas about what is right or wrong, desirable and undesireable, normal and abnormal, proper and improper. So, values are considerably particular concepts which becoming the standard of proper and improper within the society.

\section{Auteur Theory and Mise-en-scene}

Firstly, I employed Auteur Theory that was devised by André Bazin in 1951 to emphasis how Lee Daniels skills' as a movie director in manifesting or implementing his creative thinking, vision, and his values into The Butler. Auteur Theory derived from French which according to Shafrir $(2006,1)$ defined as, the auteur theory is a way of reading and appraising films through the imprint of an auteur (author), usually meant to be the director. According to that definition, the researcher observed that Lee Daniels were trying to depict the image, thoughts or values about racism towards African-American in The Butler from the point of view of a butler or to put it delicately, a black servant.

Therefore, the researcher recognised some scenes within The Butler that would be worth analysed because it contains Lee Daniels thoughts and values. As a movie director, Lee Daniels implemented his thought regarding racism by doing repetitive scenes which hold the same idea in the movie, and the portrayal of the message whether implicitlyor explicitly. His concept of implementing his idea into film also possess the same idea of how implementing Auteur Theory in the movie, The key thing is that a recognisable imprint is left on a body of films, and this may involve varying levels of creative input. (Shafrir, 2006:1)

In Auteur Theory, movie director possess important role because he/she becomes the standard of the films' quality, because the movie director is the heart of every scenes, and their values being carried out via film. Even the process of writing the script of the film, crew, actor and actresses within a film also represent the idea of the movie director. In this regards, Lee Daniels is the movie director in The Butler. This is how a movie director should take control of directing a film according to Encarta Dictionaries;

In most theater and film projects, the director is at the center of all creative decisions. He or she often selects the script and the key members of the cast and artistic staff. The director also approves the artistic design and leads the rehearsal work of the performers. As the project develops, the director, consciously or not, creates a style that ensures the integrity of the dramatic product. Although the director is rarely seen on stage or before the camera, the director's spirit imbues the performance with a characteristic sense of rhythm, color, vivaciousness, and artistic balance.(Directing, Encarta:2008) 
Consenquently, movie director has a significant role as opinion leader of the values within the film. Moreover, as an effort to constitute a critical thinking of how to understand movie director delivering their values, the researcher employed analytical method known as miseen-scene. Mise-en-scene (read meez-ahn-sen) derived from French which according to Bordwell dan Thompson (2005:112) could be defined as follow putting into the scene, and it was first applied of directing plays. Besides, Mise-en-scene according to Nelmess (2003:63) defined as follow,

\begin{abstract}
the term literally "having been put into the scene" is used to describe those visual aspect that appear within a single shot. The term has been used differently by writers about film, some limiting it to those elements recorded by the camera-object, movement, lightning, color, and so on-while others have included the art of recording itself, the focusing of shots and the movement of the camera. The quality of director's work could be read through his/her control over the mise-en-scene.
\end{abstract}

The researcher argues that the previous ideas about Mise-en-scene is emphasising on how the movie director is trying to depict the objects in a film, which is by utilising cinematographic skills, camera angles or shot. In other words, movie director tries to embed his values, perspectives and vision in a movie by continuously using repeated scenes which possess the same idea. Bordwell and Thompson (2008:115) also define that methods in utilising Mise-en-scene analysis were based on four basic components; setting, costume and make-up, lightning, and staging. In addition, Lathrop and Sutton (2014:1) also pointed out the merits of Mise-en-scene as follow, using these elements, the film director stages the event for the camera to provide his audience with vivid, sharp memories. Directors and film scholars alike recognize mise-en-scene as an essential part of the director's creative art. Therefore, by utilising four of those elements within Mise-en-scene, considerably is the pivotal key of how the movie director tries to show the natural or original representation so it would be memorable for the audiences.

Knowing that, by utilising Mise-en-scene, the researcher would distinguish and describe the values or issues that carried out by the movie director. As a result, the researcher was able to determine the scenes or screenshot, and the dialogues that shown the issues of racism towards African-American in The Butler.

\section{Thick Description}

Afterwards, the researcher interpreted and analysed the description obtained from Mise-enscene by utilising ethnographic analysis known as Thick Description developed by Clifford Geertz. Geertz through Thick Description analyse the cultural approach by studying about symbolic system, in-depth and thorough cultural values from the point of view of the subjects in cultures which frequently employed in ethnographic study. Adapting from that particular approach, the researcher was able to interpret culture and racial issues based on the context of The Butler by analysing and interpreting cultural symbols shown by the actor and actresess in the film, hence, the researcher would be able to analyse the background, objectives, and the function of the actor and actresses or the pelaku budaya when they are practicing cultural values or racism in The Butler. This statement also supported by Geertz (1973:12) as Culture is public because meaning is. It could be defined that culture is what been seen in the society and culture consists of semiology which applies in the society. 


\section{RESEARCH METHODS}

The researcher utilised Auteur Theory to emphasis the significance of the research problems that has been shown by the director, and continued by employing mise-en-scene analysis to describe and highlight races issues within the scenes in The Butler. Afterwards, the researcher analysed and interpreted the description by utilising Thick Description according to Clifford Geertz.

Aforementioned, Auteur Theory were utilised to show Lee Daniels' thoughts in implementing his creative thinking, along with his mission, and visions into The Butler. In discovering the movie director ideas, the researcher utilised mise-en-scene analysis which consist of several components; setting, costume and make-up, lightning, and staging. These components were being employed to show and categorise the context regarding the primary issues which include racism towards blacks within the scenes in The Butler. On the other hand, screenshot, scripts, or the film's narration that depicted the dialogue among the casts in The Butler, were fully utilised to understand the intimacy, personal and public context, and the cast's behaviours in the film.
However, the researcher in analysing scenes of this film stated that the most dominant component or the most shown components are setting, costume, and staging, especially the dialogue among the casts in the film.

The researcher utilised mise-en-scene to reveal the racism towards blacks, hence, keen observation, categorising, and giving description of each scenes or screenshot, and the scripts were done to complete the utilisation of mise-enscene. Each scenes and screenshot, and the scripts of the film were being analysed and interpreted by employing Thick Description which underlined the main issues that has been proposed by the researcher; racism which caused the emergence of prejudice and discrimination towards blacks. Entirely, according on the context of the film, the researcher chose the scenes and scripts that closely related or emphasise to the issues of racism towards blacks. The screenshots, the scripts and the dialogues in that film were being analysed with the intention of exposing the filmmaker's style to portray racial issues based on the context of the film. In addition, the chosen scenes also involve some ofmain casts; Cecil Gaines, the black butler, and his son, Louis Gaines, the black's civil rights movement's activist'.

\section{ANALYSIS}

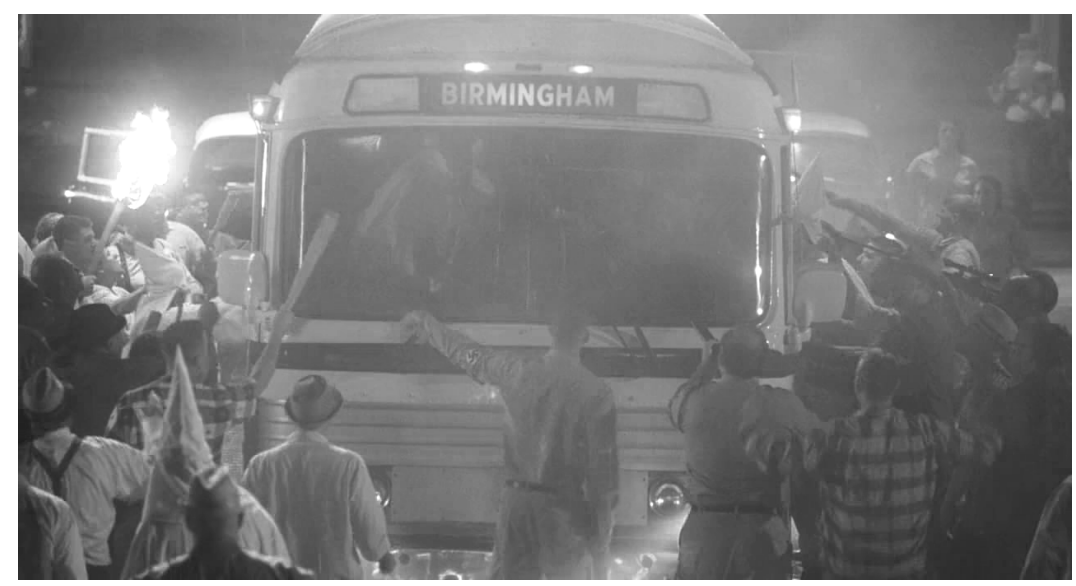

Picture 4.1: White's Racial Violence towards Freedom Riders activists: Ku Klux Klan 
The screenshot above showed the exact scene where Louis and other civil rights' activist were fighting for equality in civil rights for the black which is known as Freedom Rider. Freedom Rider is a form of of civil right's movement among the black which demanding of asking equalty in public facility, in this case public transportation or bus. In association to the definition of Freedom Riders in Encarta Dictionaries (2009); protester against racial segregation: a civil rights activist who, during the early 1960s, joined one of the interracial groups riding buses through parts of the southern United States to protes against racial segregation.

On that scene, Louis and his colleagues were riding a bus in Montgomery, Alabama. The bus that they were ride on with is not only filled up by Louis and his black colleagues, but also they were sitting side by side with white's journalist and white's sympatisers which joined force in black's civil rights movements. However, their bus was suddenly ambushed by white's people who wear particular attire which resemble $\mathrm{Ku}$ Klux Klan. During the ambush, Louis and his colleagues' bus were forcibly stopped in a bridge, hence, they were finally being attacked by white mobs who were using torch, wooden stick, and the bus was finally exploded because Molotov bomb that had been thrown towards Louis and his colleagues.

Within the chosen scene, the researcher perceives several components in mise-en-scene which shown issues about racism in which caused the discriminatory behaviours from white's people; setting, costume, and staging.

On the setting, Louis and his colleagues were depicted in the public bus when they are passing the bridge in Alabama. The bus that they were on actually belong as the public facility which dedicated towards every citizens, however the coloured people including the blacks must occupy the passengers seats only at the back. As stated by Barber and Watson (1988:91) Blacks had to ride at the back of the buses... That statement also distinguished discriminatory behaviours towards blacks, undenieably, triggers civil movements known as Freedom Riders.

Continued with costume components, in this component racism were depicted in the form of discrimination which can be seen from white attire of the white people on that scene. The whites were depicted wearing white robes with pointed cloaks which identical to Ku Klux Klan, which highly uphold white supremacy's ideology. Those white mobs which identical to Ku Klux Klan, wear that style of outfit when they perfom racism in the form of discrimination to restrain black society's civil rights. As explained by Encarta (Ku Klux Klan; 2008) below,

Attired in robes or sheets and wearing masks
topped with pointed hoods, the Klansmen
terrorized public officials in efforts to drive
them from office and blacks in general to
prevent them from voting, holding office,
and otherwise exercising their newly acquired
political rights.

Lastly, on the staging or the acting of the casts in that scene portrayed how racism had been done by white's people under the name of Ku Klux Klan towards black's civil rights movements. On that scene the white mob surround the bus that Louis and the Freedom Riders sympatiser were ride on with, besides attacking verbally that particular white mob also equipped themselves with torch and wooden stick. The behaviours shown by whites within Ku Klux Klan could be observed from this part of the dialogue; Men with torches in Klan dress and a burning cross approach the bus. They start SMASHING the bus windows with bats and chains! 
The racial behaviours continued when some of the member of the white mob who wear $\mathrm{Ku}$ Klux Klan cloak break the window and wrecked the bus which Louis ride on with, which eventually a white male wearing Ku Klux Klan's cloak throw Molotov bomb inside the bus. The bomb forcibly removed Louis and his colleagues among the Freedom Riders symphatiser to escape from the bus. As it has shown by following dialogues;

The Freedom Riders drop to the center aisle of the bus. Glass shards fall on top of them. A WHITE MAN's smiling face appears as he takes off his Klan hood. Then - he throws AMOLOTOV COCKTAIL into the bus, setting the back on FIRE!

Basing on the components of mise-en-scene the researcher argues that the attack towards the bus who Freedom Riders symphatisers were ride on with is considered as the form of discriminatory behaviours from white's as superiority feelings which reject blacks' civil rights equality. This argument is supported by Horton and Chester (1984: 231) which explain about discrimination, Discrimination involves actual behaviour; favoring one person or penalising another because of that individual's ethnic status. It usually surfaces when members of a dominant group deny equal treatment to subordinate group. Besides, according to the part of the dialogue above when the white mobs commenced attack towards Louis and his colleagues, the white mobs seem have no regrets and enjoying themselves while smiling.

Afterwards, based on the previous explanation the researcher is able to interpret that the racial behaviours that have taken form as discriminatory actions as performed by Ku Klux Klan was their attempt to assert their dominance over black. The representation of that behaviour could be seen in setting which underlying the vio- lence towards blacks' civil rights movements, particularly the attack towards Freedom Riders sympathisers. In accordance to Bordwell and Thompson (2008: 115) as follow, the Overal design of a setting can shape how we understand story action. In addition, based on setting it can be distinguished that discriminatory behaviours from Ku Klux Klan is considered as their resistance or rejection towards government policies which emphasising that blacks are equal or posses the same rights as whites. Ku Klux Klan behaviours is explained by Encarta as follow,

The Klansmen regarded the Reconstruction governments as hostile and oppressive. They also generally believed in the innate inferiority of blacks and therefore mistrusted and resented the rise of former slaves to a status of civil equality and often to positions of political power.

According to the previous explanation the researcher argues that racial behaviours from whites under the banner of Ku Klux Klan was basing on the premiss about historical-stereotyped that black was a commodity or slave and as the inferior group. Therefore, the researcher intrepeted that the racial behaviours as performed by white was their method in maintain their superiority towards blacks, in other words as a form of white supremacy among white. White supremacy that they possess made the white think that they are the superior group, and maintaining order, authority and rights over blacks. As Hooks (1992: 340) mentioned in Cultural Studies about white supremacy in the concept of white's people;

In white supremacy society, white people can "safely" imagine that they are invisible to black people since the power they have historically asserted, and even now collectively assert over black people accorded them the right to control the black gaze

The researcher is able to draw conclusions that racial behaviours from white's which led to discriminatory behaviours in form of violence and 
burning down the bus of Freedom Rider sympathiser considered as the implementation of their White Supremacy's concept. Moreover, the racial behaviours were regarded as an attempt from white, notably Ku Klux Klan, in maintaining their dominance over blacks in the use of public facilities and civil rights. Superiority feeling among whites in the aforementioned scenes emphasising that whites do not want to be treated as equal with blacks, which based on white's perspective is the inferior group. Particularly in maintaining the civil rights as the citizens of America, in which was belong only as white's special privilege.

\section{CONCLUSION}

The Butler by Lee Daniels was valued as a remembrance that, eventhough Obama were elected as the president ofAmerica, racism towards the African-Americans have not entirely vanished in America. Racism in America also distinguishes as an attempt from the white's society to assert and maintain their dominance over AfricanAmerican, thus in order to do so the white's society apply methods known as prejudice and discrimination towards African-American.

Therefore, by showing their tremendous dedication, professionalism, and work-ethics, the butler or black servants have significant roles in altering white's society perception in America regarding the negative stereotyped and stigmas that have been labeled to African-American. In conclusion, in order to reduce the negative stereotyped and stigmas towards African American at $21^{\text {th }}$ century, the African American should imitate the butler's traits to endure or reduce racism towards them; by having professionalism, discipline, perseverance, and honesty.

The researcher also concludes that CrossCultural Understanding is required as a bridge between various cultures and societies. These are the stages of how to apply the values of Cross-Cultural Understanding; become aware of your own cultural style, know the facts about the cultures you most commonly relate to, identify ways to modify your behaviours appropriate to the other culture, dan respond to other culture using your modified behaviour. 


\section{REFERENCES}

Barber, Benjamin. Watson, Patrick. 1988. The Struggle for Democracy. Boston: Little, Brown, \& Company.

Bordwell, David. Thompson, Kristin. Film Art: An Introduction. New York: McGraw-Hill. 2008. Accessed on September, $18^{\text {th }} 2015$, downloaded from http://pages.ucsd.edu/ $\sim$ bgoldfarb/cogn21w10/reading/bordwell ch4.pdf

Eugene Allen Biography. 2013. http://www. biography.com/people/eugene-allen21095473. Accessed on January, $6^{\text {th }} 2016$.

Ferris, Kerry. Stein, Jill. The Real World $2^{\text {nd }}$ Edition, an introduction to sociology. New York: W.W. Norton \& Company. 2010.

Ferrante, Joan. 2007. Sociology: A Global Perspective, Seventh Edition. Belmont: Thomson Wardsworth

Gordon, Mel. "Directing." Microsoft ${ }^{\circledR}$ Encarta ${ }^{\circledR} 2009$ [DVD]. Redmond, WA: Microsoft Corporation, 2008.

Geertz, Clifford. The Interpretation of Culture. USA: Basic Book Inc. 1973.

Hess, Beth B. Markson, Elizabeth W. Stein, Peter J. Sociology Fourty Edition. New York: Macmillan Publishing Company. 1993. Horton, Paul B. Hunt, Chester L. Sociology. New York: McGraw-Hill Education. 1984.
Hooks, Bell. Representing Whiteness in the black imagination, Cultural Studies. London: Routledge C 1992

Kornblum, William. Julian, Joseph. Smith, Carolyn D. Social Problems. New Jersey: Prentice Hall Inc. 1995.

Kurniadi, Maryono, "Kontroversi Tentang Pembangunan Islamic Center Dekat Ground Zero New York, Amerika Serikat". Tesis, Fakultas Pasca Sarjana, UI. Jakarta, 2012

Lathrop, Gail. Sutton, David O. Elements of Mise-en scene. Accessed on August 7, 2018, downloaded from http://www.prose productionsink.com/1102_Licata_ Elements_of_Mise-en-scene_modified.pdf Nelmess, Jill. An Introduction to Film Studies. New York: Routledge. 2003.

Shafrir, Doree. . Auteur Theory.Accessed onSeptember, $19^{\text {th }} 2015$, downloaded from http://sharepoint.mvla.net/teachers/GalenR/ Film\%20Analysis/Documents/Class\% 20Readings/AUTEUR\%20THEORY.pdf

Tindall, George Brown. Shi, David Emory. America: A Narrative History Vol 1. New York: WW Norton and Company. 1984.

“Ku Klux Klan.” Microsoft ${ }^{\circledR}$ Encarta ${ }^{\circledR} 2009$ [DVD]. Redmond, WA: Microsoft Corporation, 2008. 